\title{
PENGEMBANGAN MEDIA GAMBAR BERBASIS KOMPUTER DALAM PEMBELAJARAN KOSAKATA BAHASA ARAB UNTUK SISWA MAN KELAS X
}

\author{
Oleb: \\ M. Miftab
}

\begin{abstract}
Abstrak
Penelitian dan pengembangan ini bertujuan menghasillkan suatu produk pengembangan media gambar berbasis komputer yang layak untuk pembelajaran kosakata bahasa Arab bagi siswa madrasah aliyah negeri kelas $x$.

Untuk mendapatkan program yang valid diadakan ujicoba melalui 4 tahap dengan responden uji coba berjumlah 34 orang, terdiri dari: dua ahli bidang studi bahasa Arab, dua ahli media pembelajaran, dan 30 siswa kelas X MAN 3 Yogyakarta. Uji coba lapangan dilakukan untuk memperoleh masukan terhadap produk jika digunakan dalam pembelajaran. Data diperoleh melalui kuesioner dan dianalisis menggunakan teknik deskriptif kuantitatif.

Hasil penelitian adalah sebagai berikut. (1) Evaluasi ahli bidang studi bahasa Arab menunjukkan bahwa kualitas instruksional baik (nilai 4,2 pada skala 1 sampai 5), kualitas materi baik (nilai 4,1), dan evaluasi ahli media pembelajaran menunjukkan bahwa kualitas tampilan sangat baik (nilai 4,63), kualitas pem-programan baik (nilai 4,18), dan kualitas pembelajaran sangat baik (nilai 4,7). (2) Evaluasi peromangan menunjukkan bahwa produk memiliki kualitas instruksional sangat baik (nilai 4,26), kualitas materi baik (nilai 4.08), kualitas tampilan sangat baik (nilai 4,45), dan kualitas motivasi sangat baik (nilai 4,28). (3) Evaluasi kelompok kecil menunjukkan bahwa produk memiliki kualitas instruksional baik (nilai 4,17), kualitas materi baik (nilai 4,1), kualitas tampilan sangat baik (nilai 4,3), dan tingkat motivasi baik (nilai 4). (4) Uji coba lapangan menunjukkan bahwa produk memiliki kualitas instruksional baik (nilai 4,18), kualitas materi sangat baik (nilai 4,23), kualitas tampilan sangat baik (nilai 4,33), dan kualitas motivasi baik (nilai 4,2). Penelitian ini menyimpulkan bahwa produk pengembangan media gambar berbasis komputer efektif digunakan sebagai media pembelajar-an kosakata bahasa Arab siswa MAN kelas x.
\end{abstract}

Kata kunci: media gambar, pembelajaran kosakata. 


\section{Pendahuluan}

Bahasa merupakan kebutuhan vital manusia untuk berkomuni-kasi dan manusia tidak akan dapat lepas dengannya. Oleh karena itu, usaha-usaha untuk mengetahui dan menguasai bahasa sangat ramai dibicarakan oleh para ahli bahasa di seluruh dunia. Di antara bahasa yang menarik untuk diteliti bagi masyarakat Indonesia adalah bahasa Arab, karena pengaruh bahasa Arab dalam bahasa Indonesia tampak dalam bentuk pungutan kosa kata Arab ke dalam bahasa indonesia yang dapat kita perhatikan dalam berkomunikasi sehari-hari (Erwina Burhanuddin, dkk. 1993:1-2).

Sehubungan dengan banyaknya penggunaan bahasa Arab tersebut, banyak lembaga pendidikan memasukkan bahasa Arab ke dalam kuri-kulum, sehingga bahasa Arab merupakan bidang studi tersendiri yang tidak kalah pentingnya dengan bidang studi lain. Namun dalam menempuh pembelajaran bahasa Arab, masing-masing lemba-ga berbeda, sesuai dengan tujuan yang ingin dicapai. Tujuan yang ingin dicapai dalam kegiatan pembelajaran bidang studi bahasa Arab di madrasah aliyah berdasarkan ku-rikulum berbasis kompetensi yaitu, agar siswa menguasai secara aktif dan pasif dengan target penguasaan 575 kosakata dan idiom yang disusun dalam berbagai pola kalimat yang berhubungan dengan keagamaan dan kemasyarakatan, serta dapat dipergunakan sebagai alat komunikasi untuk memahami teks-teks kontemporer, baik yang terkait dengan ilmu, teknologi, seni dan masyarakat maupun keagamaan (Depag RI. 2003:1).

Berdasarkan tujuan tersebut di atas, salah satu faktor yang sangat penting adalah faktor penguasaan kosa kata. Kualitas keterampilan berbahasa seseorang jelas tergantung kepada kuantitas kosa kata yang dimilikinya. Semakin banyak kosa kata yang dimilikinya, maka semakin besar pula kemunginan bisa terampil berbahasa.

Proses belajar mengajar ditinjau dari ruang lingkupnya terdiri dari beberapa komponen atau unsur. Komponen tersebut meliputi tujuan, bahan pelajaran, kegiatan belajar mengajar, metode dan alat, serta evaluasi (Syaiful. 1996: 48). Komponen-komponen tersebut harus saling berkait satu sama lain untuk mencapai keberhasilan sesuai tujuan yang ditetapkan. Keberhasilan dalam mencapai tujuan instruksional tersebut juga tidak lepas dari berbagai hal yag 
Pengembangan Media Gambar Berbasis Komputer dalam Pembelajaran Kosakata Babasa Arab untuk Sisva MAN Kelas $X$

berkaitan dengan lingkungan bahasa, penyampai (guru) bahasa, asumsi siswa terhadap sebuah bahasa, waktu yang dipergunakan untuk belajar bahasa, metode dan media yang dipergunakan, dan lain sebagainya.

Dalam pembelajaran bahasa Arab di Indonesia sampai saat ini masih banyak guru belum menerapkan komponen pendidikan, di antaranya kurangnya sebagaian guru memahami dan memanfaatkan peran media sebagai sarana pembelajaran. Sebagai indikasinya banyak siswa kurang berminat dan motivasi untuk mempelajari bahasa Arab. Menurut Oemar Hamalik, keberhasilan proses belajar mengajar tidak lepas dari peran media di dalamnya, sebab media adalah suatu bagian integral dari proses pendidikan di sekolah (Oemar Hamalik. 1989: 1).

Akibat kurang pemahaman dan pemanfaatan peran media bagi guru dalam pembelajaran bahasa Arab, masalah berikutnya adalah menjadikan guru kurang kreatif membuat dan mengembangkan media gambar sebagai sarana/ alat penunjang pembelajaran kosa kata bahasa Arab. Sebagaimana dikatakan Ahmad Fuad Effendy (2004: 98), media gambar merupakan alat bantu pembelajaran yang dapat memperjelas makna suatu kata. Kendala lain, yaitu masih ada sebagaian guru yang menggunakan metode tradisional, yaitu dengan memposisikan guru/pengajar sebagai sentral pengembangan wacana, bukan memberikan prioritas pada pembelajaran bahasa sebagai orang yang memiliki perilaku aktif dan kreatif. Bisa jadi hal ini merupakan salah satu penyebab mengapa bahasa Arab di Indonesia, yang nota bene mayoritas penduduknya beragama Islam tidak mengalami banyak perkembangan. Lebih ironisnya lagi, kenyataan empirik bahwa tidak jarang bahasa Arab dipandang sebagai sesuatu yang serba sulit dikuasai.

Kondisi yang sering dialami oleh berbagai lembaga pendidikan formal dalam pembelajaran bahasa Arab khususnya pembelajaran kosakata, mereka kebanyakan berorientasi pada hafalan, ketimbang pada praktek berkomunikasi. $\mathrm{Hal}$ ini merupakan kelemahan mendasar dalam pembelajar-an bahasa. Kondisi demikian ini juga dialami kebanyakan madrasah aliyah (MA). Selama ini, pembelajaran bahasa Arab di MA masih sebatas penyampian materi saja, bukan pada pencapaian tujuan pembelajaran bahasa Arab. Aktivitas kelas didominasi oleh guru, sementara siswa berperan hanya sebagai objek pembelajaran, bukan 
sebagai pelaku utama dalam proses belajar mengajar. Implikasi dari pembelajaran adalah kurang inovatif dan berakibat rendahnya minat siswa terhadap mata pelajaran bahasa Arab, karena dalam penyajiannya guru kurang variatif menggunakan pendekatan, metode, dan teknik sehingga siswa kurang termotivasi.

Begitu pula dalam kegiatannya di dalam kelas, siswa benar-benar dipacu oleh guru untuk dapat menguasai kaidah-kaidah bahasa (seperti ilmu sharaf dan ilmu nahwu) dari pada penggunaan bahasa sebagai alat komunikasi, sehingga timbul kejenuhan dan kebosanan di kalangan para siswa, karena tidak adanya variasi dalam proses belajar mengajar. Oleh karena itu, kondisi pembelajaran bahasa Arab yang demikian disebut pembelajaran bahasa Arab dengan menggunakan metode tradisional.

Dalam pembelajaran, metode bukan merupakan komponen yang ada dengan sendirinya, akan tetapi merupakan tindak lanjut dari suatu pendekatan (approach). Sedangkan antara metode dan pendekatan adalah berbeda, meskipun untuk mengetahui letak perbedaan antara keduanya pada waktu diterapkan dalam pembelajaran adalah sukar. Hal ini karena pendekatan bersifat aksiomatis dan metode bersifat prosedural, sehingga metode tidak boleh bertentangan dengannya. Pendekatan pembelajaran bahasa Arab yang akan digunakan dalam tesis ini adalah pendekatan komunikatif. Tentu saja pendekatan tersebut tidak jauh berbeda dengan pendekatan pembelajaran bahasa asing lainnya yaitu didasarkan pada kompetensi komunikatif.

Kompetensi komunikatif ini merujuk kepada kemampuan kita menggunakan bahasa untuk interaksi sosial dan komunikatif, yaitu mengetahui kapan saat yang tepat membuka percakapan dan bagaimana, topik apa yang sesuai untuk situasi atau peristiwa ujaran tertentu, bentuk sebutan mana yang sesuai harus digunakan, kepada siapa dan dalam situasi apa serta bagaimana menyampaikan, menafsirkan dan merespon tindak ujaran seperti salam, pujian, permintaan maaf, undangan dan sebagainya. Hymes sendiri menggunakan istilah kompetensi komunikatif untuk merujuk kepada pengetahuan kaidahkaidah gramatikal, kosa kata, dan semantik, serta kaidah-kaidah berbicara pola perilaku sosiolinguistik masyarakat bahasa yang bersangkutan (Furqanul Azies dan Chaedar Al Wasilah. 1996:26). 

Kelas $X$

Tujuan akhir yang akan dicapai oleh orang yang mempelajari bahasa asing ialah dapat mempergunakan bahasa tersebut, baik lisan maupun tulisan dengan tepat, fasih dan bebas untuk berkomunikasi dengan orang yang menggunakan bahasa tersebut (Mulyanto Sumardi. 1974:56). Sebalik-nya tujuan dan fungsi pembelajaran bahasa Arab sebagai bahasa asing adalah untuk mengembalikan pembelajaran bahasa agar lebih bermakna dan komunikatif, sehingga setelah berlangsungnya proses kegiatan belajar mengajar bahasa Arab diharapkan nantinya siswa mampu mengungkapkan dan menyampaikan gagasannya dalam bahasa Arab dengan baik dan benar.

Melihat kondisi seperti di atas, penulis ingin mencoba memberikan kontribusi pemikiran dalam pembelajaran bahasa Arab dengan pengem-bangan media gambar berbentuk $C D$ pembelajaran, sebagai pendekatan komunikatif dalam pembelajaran kosakata bahasa Arab untuk siswa Madrasah Aliyah. Jadi dalam hal ini, siswa belajar kosakata bahasa Arab dengan menggunakan media gambar pada $C D$ pembelajaran untuk diekspresikan dalam bahasa lisan dan tulisan sebagaimana yang dicontoh-kan dalam $C D$ pembelajaran. Dengan demikian, situasi dan kondisi kelas tilex dan menyenangkan, karena menjadikan pesan atau materi lebih mudah diingat dan lebih mendalam kesannya dan materi-materi akan lebih mendekatkan siswa dengan menggunakan alat yang divisualisasikan ke dalam bentuk lain, yaitu dalam bentuk media gambar bermakna dan dapat dinikmati dengan panca indra khususnya indra penglihatan (visual), sehingga akan memotivasi dan membangkitkan gairah siswa dalam belajar bahasa Arab.

Guna menunjang tujuan pembelajaran kosakata bahasa Arab dapat tercapai dengan baik dan benar, pendidik dalam mengajarkan bahasa sudah selayaknya mencari suatu pendekatan atau metode dan media yang sesuai dengan karakteristik siswa, sehingga siswa akan menjadi lebih mudah memahami materi yang disampaikan guru. Penggunaan media pembelajar-an dan pendekatan dalam proses belajar mengajar sangat penting, karena dapat membantu memotivasi dan memudahkan siswa dalam belajar. Sehubungan dengan latar belakang di atas, peneliti ingin mencoba memberikan kontribusi melalui artikel ini dengan mengambil judul: 'Pengembangan Media Gambar Berbasis Komputer Dalam Pembelajaran Kosakata Bahasa Arab Untuk Siswa MAN Kelas Sepulub". 
Berdasarkan uraian tersebut muncul dua pertanyaan, yaitu: 1) Bagaimanakah produk pengembangan media gambar berbasis komputer dalam pembelajaran kosakata bahasa Arab untuk siswa MAN kelas sepuluh? dan 2) Apakah produk pengembangan media gambar berbasis komputer memiliki keefektifan dalam pembelajaran kosakata bahasa Arab untuk siswa MAN kelas X?

Tujuan pengembangan ada dua, yaitu: 1) Menghasilkan produk pengembangan media gambar berbasis komputer dalam pembelajaran kosakata bahasa Arab untuk siswa MAN kelas X dan 2) Mengetahui produk pengembangan media gambar berbasis komputer yang layak digunakan sebagai media pembelajaran kosakata bahasa Arab bagi siswa MAN kelas X.

\section{Metode Penelitian}

Model pengembangan dalam penelitian ini menggunakan model pengembangan yang telah dimodifikasi dari Borg dan Gall (1983), Criswell (1989), Arief S. Sadiman (1986), Alfred Bork (Walker \& Hess. 1984), yang langkah-langkahnya: (1) melakukan penelitian pendahuluan, (2) membuat desain materi pembelajaran, (3) memproduksi media gambar, (4) melaksanakan evaluasi, (5) melakukan revisi, dan (G) diseminasi dan implementasi.

Penelitian pengembangan ini melalui 5 tahap: 1). Melakukan peneliti-an pendahuluan yang meliputi (a) identifikasi kebutuhan pembelajaran, (b) identifikasi karakteristik siswa, dan (c) analisis pembelajaran. 2). Membuat desain materi pembelajaran yang meliputi; (a) membuat silabus (b) membuat naskah materi pembelajaran, (d) membuat soal-soal latihan beserta kunci jawaban, (e) membuat balikan dan ( $f$ ) menyusun evaluasi formatif. 3) Produksi pengem-bangan media gambar dengan langkah: (a) membuat flowchart, (b) membuat storyboard, (c) pengumpulan bahan image, button, musik, record, dan lain-lain (d) melakukan produksi media gambar, (e) evaluasi oleh ahli bidang studi dan ahli media pembelajaran, $(f)$ analisis, dan (g) revisi. 6). Melakukan tahap uji coba untuk memperoleh sejumlah informasi yang penting bagi keperluan revisi. Tahap ini melibatkan sejumlah subjek yakni: (a) perorangan, (b) kelompok kecil, dan (c) uji coba lapangan.

Produk dari pengembangan ini diujicoba dengan tahapan sebagai berikut: (1) validasi oleh ahli media pembelajaran, (2) validasi oleh ahli materi bahasa 
Pengembangan Media Gambar Berbasis Komputer dalam Pembelajanan Kosakata Babasa Arab untuk Siswa MAN Kelas $X$

Arab, (3) analisis hasil evaluasi oleh ahli materi dan ahli media, (4) revisi I, (5) evaluasi perorangan, (6) analisis hasil evaluasi perorangan, (7) revisi II, (8) evaluasi kelompok kecil, (9) analisis hasil evaluasi kelompok kecil, (10) revisi III, (11) uji coba lapangan, (12) analisis hasil evaluasi uji coba lapangan, (13) revisi IV, dan (14) produk akhir.

Subjek uji coba meliputi dua orang ahli media pembelajaran, dua orang ahli materi bahasa Arab, dua siswa sebagai uji coba perorangan, lima siswa sebagai uji coba kelompok kecil, dan 30 siswa kelas X Madrasah Aliyah Negeri 3 Yogyakarta semester gasal.

Data yang diperoleh dari siswa dan hasil uji coba produk dimaksudkan untuk mengetahui kualitas $C D$ pengembangan media gambar untuk pembelajaran kosakata bahasa Arab. Data tersebut diperoleh secara kuantitatif yang kemudian dibuat menjadi data kualitatif yang mencakup aspek: pembelajaran, isi/materi, tampilan serta motivasi.

Instrumen dalam penelitian berupa kuesioner untuk memperoleh data dari para ahli materi bahasa Arab, ahli media pembelajaran, dan siswa dalam rangka menilai kualitas produk. Data kuantitatif yang diperoleh melalui angket dianalisis dan dikonversikan ke data kualitatif dengan skala 5 kemudian dideskriptifkan dan hasil data tersebut dijadikan dasar untuk mengetahui kualitas produk pembelajaran.

\section{Hasil Penelitian dan Pembahasan}

\section{Data Uji Coba}

a. Data Uji Coba dan Hasil Pengembangan tahap I

1) Ahli Bidang Studi

Pada uji coba tahap pertama, evaluasi materi/bidang studi dilakukan oleh 2 ahli bidang studi bahasa Arab. Evaluasi ahli bidang studi dimaksudkan untuk memperoleh masukan tentang kualitas instruksional dan materi dari $C D$ pembelajaran.

2) Ahli Media

Pada uji coba tahap pertama, evaluasi media dilakukan oleh 2 ahli media. Evaluasi ahli media pembelajaran dimaksudkan untuk memperoleh 
masukan tentang kualitas tampilan, pemrograman, dan instruksional dari CD pembelajaran.

\section{b. Data Uji Coba dan Hasil Pengembangan tahap II}

Uji coba tahap kedua dilakukan secara perorangan, yaitu melibatkan 2 siswa berkemampuan tinggi dan rendah. Tujuan dari evaluasi tahap perorangan ini adalah untuk mengidentifikasi kekurangan produk pembelajaran setelah ditinjau ulang oleh tenaga ahli.

\section{c. Data Uji Coba dan Hasil Pengembangan Tahap III}

Uji coba tahap ketiga, yaitu uji coba kelompok kecil, melibatkan 5 siswa berkemampuan beragam dengan tujuan untuk memperoleh banyak masukan dan memantapkan sebelum uji coba sebenarnya (uji coba lapangan).

\section{d. Data Uji Coba dan Hasil Pengembangan Tahap IV}

Tahap terakhir uji coba yaitu uji coba lapangan (klasikal), bertujuan untuk penilaian kualitas CD pembelajaran sekaligus memperoleh masukan guna perbaikan, jika digunakan dalam pembelajaran. Pada waktu uji coba ini, pengembang meminta guru bidang studi bahasa Arab di lingkungan MAN 3 Yogyakarta, sebagai pengampu. Selama proses pembelajaran berlangsung, pengembang mengadakan interview dan observasi. Kegiatan interview dan observasi dimaksudkan untuk mengetahui efisiensi dan keefektifan produk.

\section{Analisis Data}

a. Analisis Uji Coba Tahap I

1). Ahli Bidang Studi

Data yang diperoleh dari hasil evaluasi oleh 2 ahli bidang studi/ materi bahasa Arab dianalisis dan digunakan peneliti untuk mengadakan perbaikan $C D$ pembelajaran kosa kata bahasa Arab yang mencakup kualitas instruksional dan kualitas materi. 
Pengembangan Media Gambar Berbasis Komputer dalam Pembelajanan Kasakata Babasa Arab untuk Sissa MAN Kelas X

2) Ahli Media

Data yang diperoleh dari hasil evaluasi oleh 2 ahli media pembelajar-an dianalisis dan digunakan peneliti untuk mengadakan perbaikan terhadap produk $\mathrm{CD}$ pembelajaran. Data tersebut meliputi aspek tampilan, pemrograman, dan instruksional.

\section{b. Analisis Uji Coba Tahap II}

Berdasarkan hasil uji coba perorangan, peneliti memperoleh data penilaian terhadap produk, kemudian dianalisis beberapa kekurangan pada produk selanjutnya dan dijadikan sebagai bahan untuk memperbaiki produk sebelum dilaksanakan uji coba kelompok kecil. Tujuan dari uji coba perorangan ini adalah untuk mengidentifikasi kekurangan produk pembelajaran setelah ditinjau ulang oleh tenaga ahli.

\section{c. Analisis Uji Coba Tahap III}

Berdasarkan hasil uji coba kelompok kecil, peneliti memperoleh data penilaian terhadap produk, kemudian dianalisis beberapa kekurangan pada produk selanjutnya dan dijadikan sebagai bahan untuk memperbaiki dan untuk lebih memantapkan produk sebelum dilaksanakan uji coba lapangan.

\section{d. Analisis Uji Coba Tahap IV}

Berdasarkan hasil uji coba lapangan, peneliti memperoleh data yang kemudian dikaji dan dianalisis, sehinggga dapat disimpulkan bahwa, secara keseluruhan produk pengembangan media gambar berbasis komputer untuk pembelajaran kosa kata bahasa Arab sudah baik dan layak menjadi media pembelajaran bahasa Arab bagi siswa.

\section{Revisi Produk}

a. Data Hasil Revisi Produk Tahap I

1) Ahli Bidang Studi

Revisi produk tahap I dilakukan setelah memperoleh data evaluasi, komentar dan saran dari ahli materi yang akan dijadikan landasan untuk merevisi 
produk sesuai dengan isian pada lembar evaluasi dan komentar atau saran para ahli materi bahasa Arab.

\section{2) Ahli media}

Revisi produk pada tahap I yang sama dilakukan setelah memperoleh data evaluasi, komentar dan saran dari ahli media pembelajaran yang meliputi kualitas tampilan, pemrograman, dan instruksional dari $C D$ pembelajaran .

\section{b. Data Hasil Revisi Produk Tahap II}

Revisi produk pada tahap II dilakukan setelah uji coba perorangan dan memperoleh data dari 2 siswa yang berkemampuan tinggi dan rendah. Data tersebut dijadikan landasan untuk merevisi produk sesuai dengan isian lembar evaluasi, yang meliputi kualitas instruksional, materi, tampilan, dan motivasi dari produk/CD pembelajaran.

\section{c. Data Hasil Revisi Produk Tahap III}

Revisi produk pada tahap III dilakukan setelah uji coba kelompok kecil yang terdiri dari 5 siswa berkemampuan campuran dan data dari 2 siswa yang bekemampuan tinggi dijadikan landasan untuk merevisi produk sesuai dengan isian pada lembar evaluasi. Revisi meliputi kualitas instruksional, materi, tampilan, dan motivasi dari produk/CD pembelajaran.

\section{d. Data Hasil Revisi Produk Tahap IV}

Revisi produk pada tahap IV dilakukan setelah uji coba lapangan (klasikal) yang terdiri dari 30 siswa dan memperoleh data dari 30 siswa yang akan dijadikan landasan untuk merevisi produk sesuai dengan isian pada lembar evaluasi dan komentar atau saran 30 siswa. Revisi meliputi kualitas instruksional, materi, tampilan, dan motivasi dari $C D$ pembel-ajaran.

\section{Simpulan}

1. Hasil penelitian menunjukkan bahwa aspek pembelajaran pada produk media gambar berbasis komputer untuk pembelajaran kosakata bahasa Arab 
memiliki kriteria baik yang ditunjukkan dari hasil coba lapangan bahwa aspek instruksional mencapai rata-rata skala 4,18.

2. Hasil penelitian menunjukkan bahwa aspek materi pada produk media gambar berbasis komputer untuk pembelajaran kosakata bahasa Arab memiliki kriteria sangat baik yang ditunjukkan dari hasil uji coba lapangan bahwa aspek instruksional mencapai skala 4,23.

3. Hasil penelitian menunjukkan bahwa aspek tampilan pada produk media gambar berbasis komputer untuk pembelajaran kosakata bahasa Arab memiliki kriteria sangat baik yang ditunjukkan dari hasil uji coba lapangan bahwa aspek tampilan mencapai skala rata-rata skala 4,33.

4. Hasil penelitian menunjukkan bahwa aspek motivasi pada produk media gambar berbasis komputer untuk pembelajaran kosakata bahasa Arab memiliki kriteria baik yang ditunjukkan dari hasil uji coba lapangan bahwa aspek motivasi mencapai skala rata-rata skala 4,2.

Berdasarkan data di atas peneliti menyimpulkan bahwa produk pengembangan media gambar berbasis komputer layak digunakan untuk pembelajaran kosakata bahasa Arab bagi siswa MAN kelas sepuluh semester gasal, karena proses pembelajarannya interaktif, tampilan produk menarik, dan penyajian materi berkualitas dan dapat meningkatkan motivasi belajar siswa terhadap pembelajaran kosakata bahasa Arab.

\section{Saran-saran}

Saran Pemanfaatan Produk

1. Pengembangan media gambar berbasis komputer sebaiknya dilakukan dengan tahap-tahap antara lain: melakukan penelitian pendahuluan, pembuatan desain produk yang meliputi pembuatan naskah, storyboard, dan flowchart view, pengumpulan bahan, perekaman dan pengumpulan audio, mengembangkan produk awal, melakukan evaluasi produk awal, melakukan revisi terhadap produk awal, mengembangkan produk akhir, evaluasi yang dilakukan oleh ahli bidang studi yang berkompeten dan ahli media pembelajaran yang berpengalaman, evaluasi satu-satu untuk memperoleh koreksi dari kekurangan dan kesalahan secara nyata, evaluasi kelompok 
kecil, yang diperlukan untuk memperoleh masukan lebih mendalam tentang kelemahan dan produk yang diharapkan sebelum produk digunakan dalam uji coba lapangan, dan uji coba lapangan yang dilakukan untuk memperoleh masukan siswa, jika digunakan dalam pembelajaran kosa kata bahasa Arab yang sebenarnya.

2. Supaya produk pembelajaran ini berkualitas dan dapat menghasilkan suatu pembelajaran yang maksimal, maka sebaiknya evaluasi yang diberikan memuat materi secara keseluruhan yang didasarkan pada standar kompetensi yang ada dalam kurikulum sekolah, feedback yang diberikan, dan sistem penilaian yang baik.

3. Agar hasil produk lebih maksimal dan layak digunakan lebih jauh lagi, maka diperlukan sebuah tim pengembang yang antara lain terdiri dari pihak pengembang kurikulum, ahli bidang studi bahasa Arab yang profesional, ahli media pembealajaran, dukungan dana, waktu yang tersedia, dan kemampuan sarana-prasarana yang memadai.

Pengembangan Produk Lebih Lanjut

1. Produk CD pembelajaran kosakata bahasa Arab sebagai langkah awal, hendaknya dikembangkan untuk materi pokok yang lain.

2. Pengembangan ini dirancang untuk pembelajaran mandiri, namun dapat digunakan sebagai pembelajaran kelompok maupun klasikal.

3. Pengembangan media gambar untuk pembelajaran kosakata bahasa Arab juga dapat dikembangkan untuk sistem evaluasi terpadu.

\section{Daftar Pustaka}

AECT. (1977). Definisi teknologi pendidikan. Jakarta: PT. Raja Grafindo Persada. Al- Imam Al- Hafidz. (1995). Shabib al turmudzi. Libanon: Lidaru Ahya Ahmad F. (2004). Metodologi pengajaran babasa Arab. Malang: Misykat.

Arief Sadiman, dkk. (1993). Media pendidikan, pengertian, pengembangan dan pemanfatannya. Jakarta: CV. Rajawali.

Borg, W.R. dan Gall, M.D. (1983). Educational reaseacr: An introduction, fourth edition. New York: Longman. 
Pengembangan Media Gambar Berbasis Komputer dalam Pembelajanan Kasakata Babasa Arab untuk Siswa MAN Kelas X

Criswell, E.L., (1989). The design of computer-based instruction. New York: Macmillan Publishing Company.

Depag RI. (2003). Kurikulum dan hasil belajar. Babasa Arab Madrasab Aliyah. Jakarta: Dirjen Kelembagaan Agama Islam.

Furqanul Azies, dan Chaedar, A. (1996). Pengajaran bahasa komunikatif, teori dan praktek. Bandung: PT. Remaja Rosdakarya.

Jos Daniel Parera. 1987. Linguistik edukasional. Jakarta: Penerbit Erlangga.

Kemp, J.E., \& Dayton, D.K. (1985). Planning and producing instructional media (Fifth Edition). New York: Harper \& Row Publishers, Inc.

Mulyanto Sumardi. (1974). Pengajaran babasa asing sebuab tinjauan dari segi metodologi. Jakarta: Bulan Bintang.

Oemar Hamalik. (1986). Media pendidikan. Bandung: Penerbit Alumni.

Syaiful Bahri. (1996). Strategi belajar mengajar. Jakarta: Rineka Cipta.

Savignon S.J. (1983). Communicative competence: theory and classroom practice. Texts and contexts in second language learning. Massachusett: Addison-Wesley Publishing Company.

Walker. \& Robert. (1984). Instructional software: Principles and perspectives for desaign and use ( $\not p$ 204-215). California: Wadsworth, Inc. 